\section{AJHSE Vol: 1 (1): 64-72, 2020}

Article Ref. No.: AJHSE-0101-05

Accepted Date: Feb. 03, 2020

(C) 2020. CC License 4.0

www.ajhse.org

African Journal of Health, Safety and Environment

An official publication of the

Applied Environmental Bioscience and Public Health Research Group

University of Benin, Benin City, Nigeria

Open Access | Bi-annual | Peer-reviewed | International

ISSN (Online): 2695-1819 | ISSN (Print): 2695-2386

\title{
MICROFLORAL COMPOSITION OF GASTRO-INTESTINAL TRACT OF BROILER CHICKENS EXPOSED TO FEED FORMULATIONS FROM FERMENTED CASHEW APPLE RESIDUE
}

\author{
${ }^{1}$ Akinnibosun, F. I., ${ }^{1}$ Omonigho, S. E. and ${ }^{* 2}$ Oyetayo, M. A. \\ ${ }^{1}$ University of Benin, Department of Microbiology, Faculty of Life Sciences, PMB 1154, Benin City, Edo State, Nigeria \\ ${ }^{* 2}$ Department of Science Laboratory Technology, Faculty of Applied Sciences, Rufus Giwa Polytechnic, P.M.B. 1019, Owo, Nigeria \\ *Email: michaelococcus@gmail.com
}

\begin{abstract}

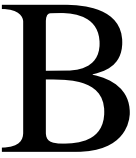

roiler feed was formulated from fermented cashew apple residue (CAR) and its effect on the intestinal microflora balance of the birds was evaluated. CAR was subjected to fermentation by Lactobacillus plantarum before being incorporated into the feed. The feeds were formulated by substituting maize with CAR at three levels: 100:0 (Diet A), 50:50 (Diet B), and 70:30 (Diet C) maize to CAR. Forty Day-old chicks were placed on the formulated feed for 6 weeks until they reached table size weight $(2.2-2.5 \mathrm{Kg})$. The results indicated a slight difference in the colour and formation of the faeces of the experimental birds and there were no significant differences in the feed intake of the treatment groups and the control during the trial period. There were no significant differences in the feed conversion ratio $(1.531 \pm 0.02$ to $1.710 \pm 0.01)$ and the total weight gain $(2.226 \pm 0.08$ to $2.355 \pm 0.10$ ) of the experimental groups and the control. Further, there was a higher level of lactic acid bacteria in the intestine of the groups fed with the feed containing fermented CAR recording $3.8 \times 10^{7}$ and $2.9 \times 10^{7} \mathrm{cfu} / \mathrm{g}$ compared with the controls $\left(2.2 \times 10^{7} \mathrm{cfu} / \mathrm{g}\right)$. Also, the total Enterobacteriaceae, E. coli and Salmonella counts in the intestinal content of the birds fed with the formulated feed containing the CAR were significantly lower than those found in the control group. These suggest that the cashew apple residue does not have negative effect on the intestinal microflora balance of the birds therefore, it may be used in the poultry feed formulation since it is cheap and available in large quantities during maize scarcity.
\end{abstract}

Keywords: broiler, Cashew apple residue, feed, fermentation, GIT, health, microflora

LICENSE: This article by African Journal of Health, Safety and Environment (AJHSE)is licensed and published under the Creative Commons Attribution License 4.0 International License, which permits unrestricted use, distribution, and reproduction in any medium, provided this article is duly cited.

COPYRIGHT: The Author(s) completely retain the copyright of this published article.

OPEN ACCESS: The Author(s) approves that this article remains permanently online in the open access (OA) mode.

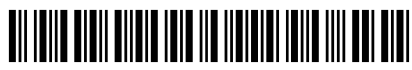




\section{INTRODUCTION}

Most Nigerians depends on animal products as their main source of dietary protein (Atteh, 2003). Many experts (Oyedejiet al., 2003; Aromolaran and Igbaro, 2007) believe that poultry production can play a role in increasing food sufficiency in the country. Availability of poultry can make positive contributions to the diet of those with low incomes, as poultry meat is consistently of high quality, low in saturated fats, as well as healthier and more affordable when compared with other meats. Thus, it is a source of essential nutrients and widely sought after worldwide (Teo and Tan, 2007). Recently, especially in the current government head by President Buhari (2015 till date), the Nigerian government at all levels have been making efforts to diversify the economy to agro-based type and many people are encouraged to go into farming especially poultry production as revealed in the NPower Agro empowerment scheme.

Considering the fast population growth around the world especially in Sub-Saharan Africa and particularly in Nigeria where population is expected to be over 400 million by 2050 (Reed and Mberu, 2014) there is need to increase food production to meet the nutritional requirements of this population. Presently, there is a great pressure on the agriculture sector of the economy of the country due to the catastrophic effect of the ongoing insurgency in the Northern Eastern part of the country and the increase in the herder-farmer clashes in other parts of the country leading to the shortage of food production in the country. These and many other factors have made maize which is the major energy ingredients in poultry feed production in Nigeria more expensive with the attendant increase in the cost of production of poultry products (Oladejo and Ladipo, 2012). Alternative sources of energy are being sought to reduce the pressure on the maize market. One of these alternatives is the use of industrial and agricultural wastes in the formulation of animal feed (Akinnibosun and Oyetayo, 2018). There is currently the search for alternative to feed development by a number of researchers who are looking at different types of agricultural wastes as potential source of feed ingredients in animal feed formulation (Kung et al., 2000; Aba et al., 2005, Shaban and Omaima, 2010). One of such alternatives are wastes generated from cashew.

Cashew is generally grown for its nut which is traded in the world market while only a minute portion of the apple is consumed worldwide (Swain and Barbuddhe, 2007). There is no record of cashew apple residue processing in Nigeria where it is either consumed fresh from farm or left to rot in farm (Abdul and Peter, 2010). Cashew apple residue is the solid mass left after the juice has been extracted and it is usually thrown away as wastes. The cashew apple residue contain high level of sugar, fibre, lipids, minerals and vitamins (Augustin, 2001) which make it a potential source of ingredient in animal feed formulation since it has comparable energy yielding potential to other sources that have been investigated for inclusion in poultry feed such alternatives includes sorghum and cassava chips (Fanimoet al., 2003; Aba et al., 2005; Swain and Barbuddhe, 2007; Akinnibosun and Oyetayo, 2019).

Despite these huge potentials of the cashew apple waste, it is usually rejected by animals due to the high content of tannin in the skin of the apple which gives a characteristic unpalatable taste (Akinnibosun and Oyetayo, 2018b). In addition, tannins are reported to possess antimicrobial activities which may have negative impact on the gut microflora of the animals (Okpanachiet al., 2016). Hence, to mitigate these challenges, cashew apple may be fermented before incorporation into the animal feed as ingredient.

Intestinal microorganisms particularly the bacteria play important role in digestive system of animals because they influence the digestion of food components by secreting digestive enzymes which aid the breaking down and 
absorption of food parts. Also, they influence the development of gut immunity and thus may prevent colonization of pathogens in the intestine (Mead, 2000).In poultry rearing, it has been observed that the populations of bacteria in the digestive tract changes according to the age of chickens and can be influenced by diet (Bineket al., 2000) as well as by many environmental factors. Consequently, metabolic stress associated with composition of the diet and environmental and management stressors can affect the balance among the microbial population of the gastro intestinal tract, impairing the growth, feed conversion, health and welfare of chickens (Proiettiet al., 2009). Therefore, this study was undertaken to assess the effect of the feed formulated from fermented cashew apple residue on the intestinal flora of broiler chickens.

\section{MATERIALS AND METHODS \\ COLLECTION AND PREPARATION OF PLANT SAMPLES}

Fresh cashew fruits (Anacardium occidentale Linn.) yellow variety, were harvested from parent plants at a Farm Plantation in Iyere, Owo, Ondo State, Nigeria. The plant material was identified at the herbarium section of the Department of Crop Production Technology of Rufus Giwa Polytechnic, Owo, Nigeria and a voucher specimen (XV201AO) was deposited. The cashew fruits were rinsed in sterile distilled water to remove the debris and sorted to discard the unwholesome ones. Then, nuts were removed manually; apples were sliced, crushed with a blender and the juice filtered. The residue was collected for further analyses.

\section{FERMENTATION PROCEDURE}

The fresh cashew apple residue was subjected to fermentation with Lactobacillus plantarum obtained from the stock of Postgraduate Laboratory of the Department of Microbiology, Federal University of Technology, Akure. It was maintained on MRS agar slant until used (Akinnibosun and Oyetayo, 2018b). A portion of $1 \mathrm{~kg}$ of the residue was added to $2 \mathrm{~L}$ of sterile distilled water and sterilized in an autoclave at $121^{\circ} \mathrm{C}$ for 15 minutes. Thereafter, the container was inoculated with $10^{6} \mathrm{CFU}$ inoculum of the L. plantarum aseptically and then covered tightly. The setup was allowed to stand for $72 \mathrm{hr}$ at room temperature $\left(28 \pm 2{ }^{\circ} \mathrm{C}\right)$ with intermittent mixing at $24 \mathrm{hr}$ interval. At the end of the fermentation, the cashew apple residue was oven dried at $62^{\circ} \mathrm{C}$ for $6 \mathrm{hr}$ (Fanimo et al., 2003).

\section{FEEDS AND INGREDIENTS}

Broiler mash (Super Starter) and Premix concentrate were procured from the depot of a manufacturer in Owo. Maize (yellow type) and wheat bran were purchased from farmer's store located in Owo.

\section{EXPERIMENTAL FEED FORMULATION}

The experimental feed was formulated by substituting maize with fermented cashew apple residue (CAR) at three levels: 100:0 (Diet I), 50:50 (Diet II), and 70:30 (Diet III) maize to CAR. These were mixed with appropriate level of premix concentrates and wheat offal (Akinnibosun and Oyetayo, 2019).

EVALUATION OF THE EFFECT OF FORMULATED FEEDON BROILER CHICKEN Animal handling and feeding trial 
Forty-day old broiler chickens were weighed to monitor the weight change and randomly assigned to 4 groups of 10 chicks each in 4 crater battery brooders $(60 \times 60 \mathrm{~cm})$. The brooders were accommodated in an environmentally controlled room with $24 \mathrm{~h}$ of lighting using 200-Watt bulbs to generate heat regulated to $32{ }^{\circ} \mathrm{C}$ which was gradually reduced after day 3 until it was no more needed. The 4 dietary treatments were then assigned to each group thus; A received Commercial diet, B received Diet I, C received Diet II and D received Diet III. The birds were transferred to iron cages after two weeks. The cages were housed in a well-ventilated pen house. Feed and water were provided $a d$ libitum throughout the experimental period. Weight gained and mortality were noted and recorded during the trial period. On day 42 , three birds from each group were slaughtered and the small intestine was removed and taken to the laboratory in icepacks analysis of gut microflora (Teo and Tan, 2007).

\section{ISOLATION AND ENUMERATION OF THE FAECAL MICROFLORA IN THE G.I.T OF BROILER CHICKEN}

One gram of the ileum content from experimental birds were taken and weighed aseptically into different test tubes containing $9 \mathrm{ml}$ each of sterile distilled water, with the aid of sterile pipette, further dilutions to $10^{5}$ were obtained. An aliquot of $0.1 \mathrm{ml}$ each of the dilutions $10^{5}$ were dispensed into sterile Petri dishes. Sterile molten Nutrient agar (Total heterotrophic bacteria count) MacConkey (for enumeration of Enterobacteriaceae) Eosin methylene Blue (selective for E. coli), and Salmonella-Shigella agar (selective for Salmonella and Shigella) and MRS agar (Lactobacilli) was poured over the inoculums evenly. The plates were incubated anaerobically at $37^{\circ} \mathrm{C}$ for $48 \mathrm{hrs}$ for MRS agar while others were incubated for $24 \mathrm{hrs}$. After incubation, total plate count was done.

\section{CHARACTERIZATION OF BACTERIAL ISOLATES}

\section{Cultural and morphological characteristics of the colonies}

The cultural and morphological characteristics of the colonies were observed based on the criteria of Bergey's Manual of Determinative Bacteriology (2001). These include the following; shape of the colonies, the elevation, the edge, optical characteristics and pigmentation.

\section{Biochemical characterization}

Biochemical characterization of the isolates was done including Gram staining reaction, motility, sugar fermentation, oxidase, citrate utilization, urea hydrolysis, catalase and coagulase tests (APHA, 1998).

\section{STATISTICAL ANALYSIS}

Unless otherwise indicated, results are expressed as means \pm SEM of three replicates. Data were subjected to oneway analysis of variance (ANOVA) using SPSS version 25.0. The Duncan's Multiple Range test was used to separate the means at the $5 \%$ level of probability.

\section{RESULTS AND DISCUSSION}


Feed and its efficient conversion to the basic component is important for the optimal performance in animal keeping especially poultry production. The gut combines nutrition, immunology, physiology and microbiology to play key role in ensuring the digestion and absorption of food parts for good growth of the animals (Apajalahtiet al., 2001). If this vital organ is destabilized by any substance such as feed ingredients especially its microbiota, the result may be detrimental to the feed intake and conversion which invariably leads to low growth rate and susceptibility to diseases with the attendant economic loss. In this study, the results shown in Table 1 reveals the comparison between faecal characteristics, feed intake, feed conversion ratio and weight gain by broilers fed with feed formulated from cashew apple residue and commercially available feed in Nigeria. There was a little difference in the appearance of the faeces of the experimental birds. The group that were fed with feed containing fermented cashew apple residue had excrement which was tainted yellow whereas, those fed with maize based diet had brown colour. The yellow coloration may be due to the colour of the cashew apple used in the feed formulation, cashews are known to produce strong pigments (yellow and red) (Akinnibosun and Oyetayo, 2018a). This may play an important role in acceptability of the feed by the birds.

Table 1: Faecal characteristics and mortality in broilers fed with fermented cashew apple residue

\begin{tabular}{|c|c|c|c|c|c|}
\hline Group & Faecal characteristics & Mortality & $\begin{array}{c}\text { Feed intake } \\
(\mathrm{Kg})\end{array}$ & FCR & $\begin{array}{c}\text { Weight gain } \\
(\mathrm{Kg})\end{array}$ \\
\hline $\bar{A}$ & $\begin{array}{l}\text { Brown with prominent white } \\
\text { patch semi formed with paste } \\
\text { consistency }\end{array}$ & 3 & $4.299 \pm 0.07^{\mathrm{a}}$ & $1.531 \pm 0.02^{\mathrm{a}}$ & $2.275 \pm 0.15^{\mathrm{a}}$ \\
\hline B & $\begin{array}{l}\text { Brown, semi formed sparse } \\
\text { white patch, watery }\end{array}$ & 2 & $4.451 \pm 0.18^{\mathrm{a}}$ & $1.560 \pm 0.20^{\mathrm{a}}$ & $2.355 \pm 0.10^{\mathrm{a}}$ \\
\hline $\mathbf{C}$ & $\begin{array}{l}\text { Yellowish grey, formed, } \\
\text { prominent white patch tainted } \\
\text { yellow }\end{array}$ & 0 & $4.207 \pm 1.00^{\mathrm{a}}$ & $1.710 \pm 0.01^{\mathrm{ab}}$ & $2.226 \pm 0.08^{\mathrm{a}}$ \\
\hline D & $\begin{array}{l}\text { Grey with a tint of yellow, } \\
\text { formed with trace of white } \\
\text { patch }\end{array}$ & 0 & $4.445 \pm 0.10^{\mathrm{a}}$ & $1.622 \pm 0.00^{\mathrm{a}}$ & $2.352 \pm 0.15^{\mathrm{a}}$ \\
\hline
\end{tabular}

Values are mean \pm SEM and values followed by different superscripts along columns are significantly different at $\mathrm{p} \leq 0.05, \mathrm{~A}=$ birds placed on commercial diet, $\mathrm{B}=$ birds placed on $100 \%$ maize diet, $\mathrm{C}=$ birds placed on 50:50 maize: CAR diet,

$$
\mathrm{D}=\text { birds placed on 70:30 maize: CAR diet. }
$$

Moreover, there was no significant differences in the overall feed intake of the treatment groups and the controls during the 6 weeks trial period however, a slight decrease was observed in the feed intake of the group fed with 50\% fermented cashew apple with $4.207 \mathrm{~kg}$ of feed consumed compared with the group fed with $100 \%$ based maize feed which consumed $4.451 \mathrm{~kg}$ per bird. Similarly, there was no significant $(\mathrm{P} \leq 0.05)$ difference in the feed conversion ratio and overall weight gain by the birds in all the trial groups and the control. This is an indication that the incorporation of the cashew apple residue has no negative implication on the growth of the birds (Mead, 2000). Feed 
conversion ratio (FCR) is used to measure the feed efficiency of feed component (Teo and Tan, 2007), therefore the insignificant differences in the FCR of the trial groups and the control suggests that the feed efficiency of broiler diets may not be negatively affected by incorporation of cashew apple residue.

Furthermore, the non-significant differences in the overall weight gain in all the groups suggest that the fermented cashew apple residue may be a veritable alternative source of energy in poultry feed formulation. Earlier in their study, Swain and Barbuddhe (2007) observed a lower feed consumption in Japanese quail layers fed with cashew apple waste and cashew nut shell compared with the control and the reduction in feed intake correlates with increase in the cashew apple content of the feed. This may be linked with the high level of tannin in cashew apples which confer on the apple an astringent taste and smell which is a factor in its rejection by animals and man according to Okpanachiet al. (2016). The high level of acceptance of the cashew apple residue by the experimental birds in this study may be due to the fermentation process it had undergone before being used in the feed formulation. Fermentation is a known food processing technique that is capable of reducing the anti-nutrient factors such as tannin in food materials.

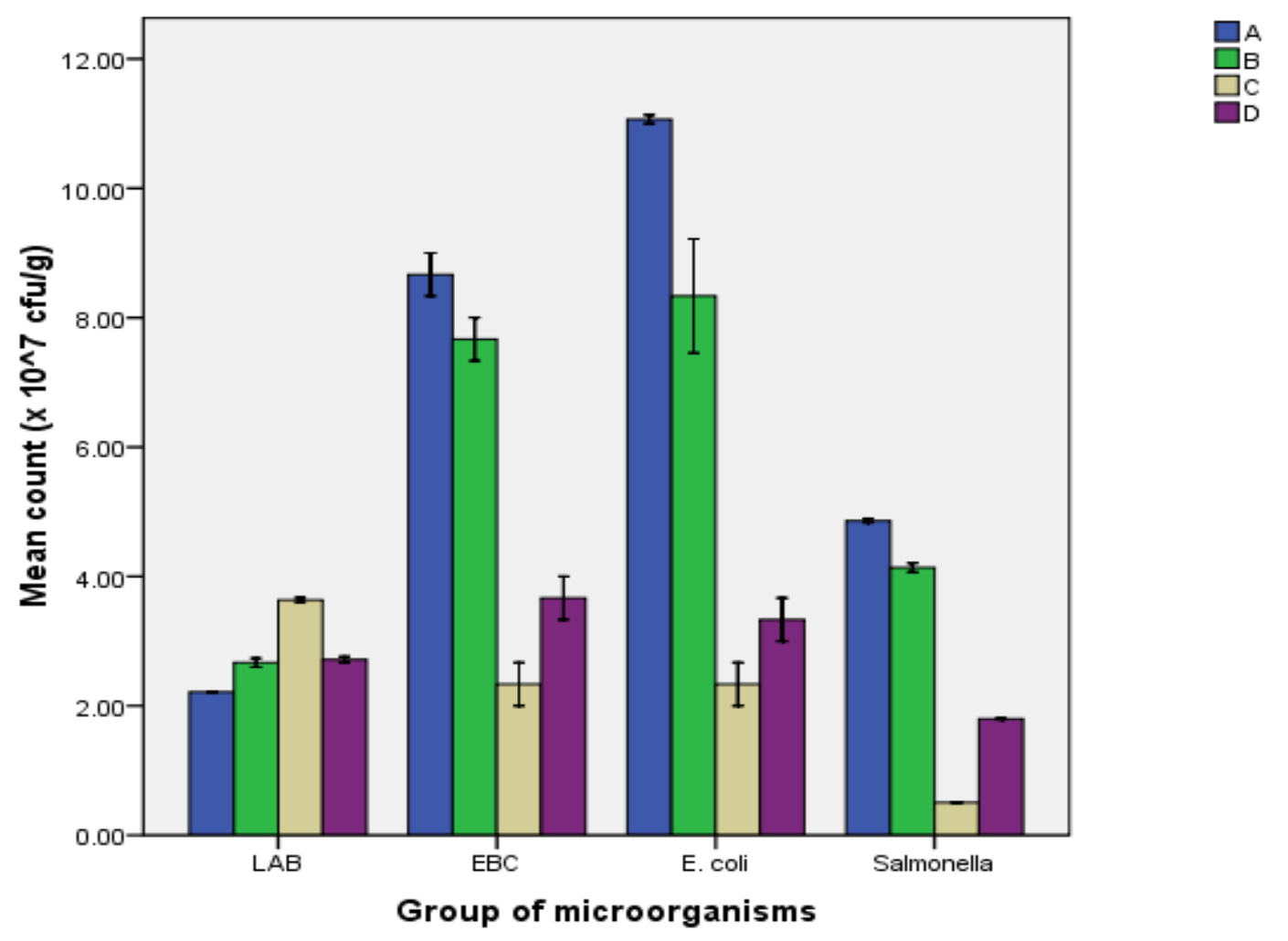

Figure 1: Count in the gut of broilers fed with feed formulated from fermented cashew apple residue Key: $\mathrm{LAB}=$ Lactic acid bacteria group, $\mathrm{EBC}=$ Enterobacteriaceae group, $\mathrm{A}=$ birds placed on commercial diet, $\mathrm{B}=$ birds placed on $100 \%$ maize diet, $\mathrm{C}=$ birds placed on 50:50 maize: $\mathrm{CAR}$ diet, $\mathrm{D}=$ birds placed on 70:30 maize: CAR diet. 
Figure 1 reveals a slightly higher level of lactic acid bacteria in the intestine of the groups fed with the feed containing fermented cashew apple residue recording $3.8 \times 10^{7}$ and $2.9 \times 10^{7} \mathrm{cfu} / \mathrm{g}(\mathrm{C} \& \mathrm{D})$ compared with the controls. This may be due to the fact that the cashew apple was fermented with a strain of lactic acid bacteria which may have been persistent in the feed. Also, the total Enterobacteriaceae, E. coli and Salmonella count encountered in the intestinal content of the birds fed with the formulated feed containing the cashew apple residue were significantly lower than those found in the other groups. This is an indication that the formulated feed may help in the control of intestinal pathogens in birds and also help maintain healthy gut flora balance. The lower counts of the E. coli and Salmonella may be linked with the activity of the residual tannins in the cashew apple residue used in formulating the feed, tannins are known to possess antimicrobial activities (Daramola, 2013). Also, it may be due to the successful colonization of the intestinal wall by the lactobacilli in such a number that help to out compete the gram-negative bacteria

In healthy animals, the concentration of the bacteria is higher in jejunum, ileum and the colon parts of the intestine where too high number of bacteria may lead to development of infection by E. coli Salmonella and other opportunistic bacteria such as Clostridium species, Klebsiella species and Staphylococcus species. However, probiotic bacteria, have been shown to stimulate healthy gut structure and systemic immune system in animals. Intestinal microflora can also be improved by changing intestinal acidity by increasing lactic acid concentration in the intestine, reducing the activities of harmful bacteria (Salmonella and E. coli), and increasing lactobacilli. Chichlowski et al. (2007) reported that use of probiotic and prebiotic products can improve intestine bacteria balance and the results obtained in this study supports this.

Gastrointestinal disease is one of the most important problems in poultry industry after coccidiosis and concerns of antibiotics resistance have led to the reduction of the use of antibiotics in poultry feeds. Hence, new trend has emerged toward the use of probiotics to control intestinal pathogens. The effect of a moss prebiotic on gut morphology and microbial intestine population in broiler chickens was studied by Rakhshan et al. (2010). No significant difference was observed in the microbial number of lactobacilli and coliforms of intestinal contents among the different groups. Therefore, cashew apple residue may be used as a potential prebiotic or better still a probiotic feed additive in poultry feed production when it is subjected to appropriate treatment particularly fermentation.

\section{CONCLUSION}

This study has demonstrated the positive effect of incorporation of fermented cashew apple residue into poultry feed by not interfering negatively on the growth of the birds as shown by the total feed intake, feed conversion ratio and total weight gain. Furthermore, incorporation of cashew apple residue into feed of the birds helps reduce intestinal pathogens and at the same time increase the beneficial microorganism thereby keeping the microflora balance of the birds' gastrointestinal tract. 


\section{REFERENCES}

Aba, D.A., Abu, E., Chindo, P.S., Marle, P.S., Maigida, D.N. and Ogungbile, A.O. (2005). Characterization of some released sorghum varieties for food and industrial utilization in Nigeria. Agriculture Tropica et Subtropica 38(2):32-40.

Abdul Salam, M. and Peter, K.V. (2010). Cashew, a monograph. (1st ed., pp. 2). India,Studium Press Pvt. Ltd

Akinnibosun, F.I. and Oyetayo, A.M (2018b). Effect of different treatment on the proximate and antinutritional content of Nigerian cashew apple residue.Ovidius University Annals of Chemistry 29 (2): 68 - 71

Akinnibosun, F.I. and Oyetayo, A.M (2019). Investigation of the Effect of Maize Substitution with Fermented Cashew Apple Residue on Broiler Chicken Growth. Notulae Scientia Biologiae, 11(4):1-5. DOI: $10.15835 / \mathrm{nsb} 11410539$

Akinnibosun, F.I. and Oyetayo, A.M. (2018a). Turning agricultural wastes to wealth in nigeria: a review of cashew (Anacardium occidentaleL.) peduncle (apple) potentials. Nigerian Research Journal of Engineering and Environmental Sciences 3(1): 57-64

Alexander, R. (2013). Does a child die of hunger every 10 seconds? BBC NEWS Magazine. Accessed September 11, 2019. http://www.bbc.co.uk/news/magazine-22935692

Apajalahti, J.H.A., Ketunen, A., Bedford, M.R. and Holben, W.E. (2001). Percent G+C profiling accurately reveals diet-related differences in the gastrointestinal microbial community of broiler chickens. Applied Environmental Microbiology. 67 (1):5656-5667

APHA (1998). Standard Methods for the Enumeration of Water and Waste water. (20th ed., pp 38). Washington DC., United States.

Aromolaran, A.B. and Igbaro, J.A. (2007). Analysis of household consumption pattern of animal products in Southwestern Nigeria. In proceeding of the Silver Anniversary Conference of the Nigerian Society of Animal Production (NISAP). (1st ed., pp. 231-232). Calabar, Unity Press.

Atteh, I.O. (2003). Romancing the chicken. 68th Inaugural Lecture, (pp. 31-37). University of Ilorin, Ilorin. Unilorin Press.

Augustin A (2001). Utilization of cashew apple. In: Souvenir of World Cashew Congress2001, India.(1st ed., pp. 57). The Cashew Export Promotion Council of India, Cochin.

Boone, D.R., Castenholz, R.W. and Garrity, G.M. (2001). Bergey's Manual of Systematic Bacteriology). (Vol 1, 2nd ed., pp. 46-60). New York, Springer.

Binek, M., Borzemska, W., Pisarski, R., Blaszczak, B., Kosowska, G., Malec, H. and Karpinska, E. (2000). Evaluation of the efficacy of feed providing on development of gastrointestinal microflora of newly hatched broiler chickens. Archive Geflugelkd. 64 (1):147-151.

Chichlowski, M., W. J. Croom, F. W. Edens, B. W. McBride, R. Qiu, C. C. Chiang, L. R. Daniel, G. B. Havenstein, and M. D. Koci. (2007). Microarchitecture and spatial relationship between bacteria and ileal, cecal, and colonic epithelium in chicks fed a direct-fed microbial, PrimaLac, and salinomycin. Poultry Science. 86 (1):1121-1132

Daramola, D. (2013). Assessment of some aspects of phyto-nutrients of cashew apple juice of domestic origin in Nigeria, African Journal of Food Science 7 (1) 107-112. 
Fanimo, A.O., Oduguwa, O.O., Alade, A.A., Ogunnaike, T.O. and Adesehinwa, A.K. (2003). Growth performance, nutrient digestibility and carcass characteristic of growing rabbits fed cashew apple waste. Livestock Research for Rural Development 15(8):1-8.

Kung, Jr. L., Robimson, J.R., Ranjit, N.K., Chen, J.H., Golt, C.M. and Pesek, I.D. (2000). Microbial populations, fermentation end-products and aerobic stability of cron silage treated with ammonia or a propionic acidbased preservative. Journal of Dairy Science. 83:1479-1486.

Mead, G.C. (2000). Prospects for competitive exclusion treatment to control salmonellas and other foodborne pathogens in poultry. Veterinary Journal 159 (1):111-123.

Okpanachi, U., Ayoade, J.A. and Tuleun, C.D. (2016). Composition and anti-nutritional factors (phyto-nutrients) present in both red and yellow varieties of sun-dried cashew pulp, American Journal of Food Science and Health 2 (2): 45-48.

Oladejo, J.A. and Ladipo, O.O. (2012). Supply analyses for maize in Oyo and Ogun states of Nigeria. International Journal of Life Sciences and Pharma Research, 2(2):8-18.

Oyedeji, I.O., Atteh, I.O. and Adedeji, S.A. (2003). Response ofbroilersto skip-a-day (SAD) feeding. Nigerian Journal of Animal Production 30(2): 162-165.

Proietti, P.C., Dal Bosco, A., Hilbert, F., Franciosini, M.P. and Castellini, C. (2009). Evaluation of intestinal bacterial flora of conventional and organic broilers using culture-based methods, Italian Journal of Animal Science, 8(1): 51-63, DOI:10.4081/ijas.2009.51

Rakhshan, M., Shivazad, S., Mousavi, M. and Zaghari, M. (2010). The effect of probiotics teknomoss on gut morphology and intestinal bacterial population in broiler chicken. In:4th Iranian Animal Science Congress, (pp. 703-706) Tehran University, Tehran-Karaj, Iran.

Reed, H.E. and Mberu, B.U. (2014). Capitalizing on Nigeria's demographic dividend: reaping the benefits and diminishing the burdens. Etude Journal of African Population, 27(2): 319-330. Doi:10.11564/27-2-477

Shaban, D.A. and Omaima, M.S. (2010). The utilization of agricultural waste as one of the environmental issues in Egypt (A case study). Journal of Applied Sciences Research, 6(8): 1116-1124.

Swain, B.K. and Barbuddhe, S.B. (2007). Effect of feeding cashew apple waste and cashew nut shell on the performance of Japanese quail layers. Indian Journal of Animal Nutrition 24(2): 92-94.

Teo, A.Y. and Tan, H.M. (2007). Evaluation of the Performance and Intestinal Gut Microflora of Broilers Fed on Corn-Soy Diets Supplemented with Bacillus subtilis PB6 (CloSTAT). Journal of Applied Poultry Research, 16 (1):296-303 